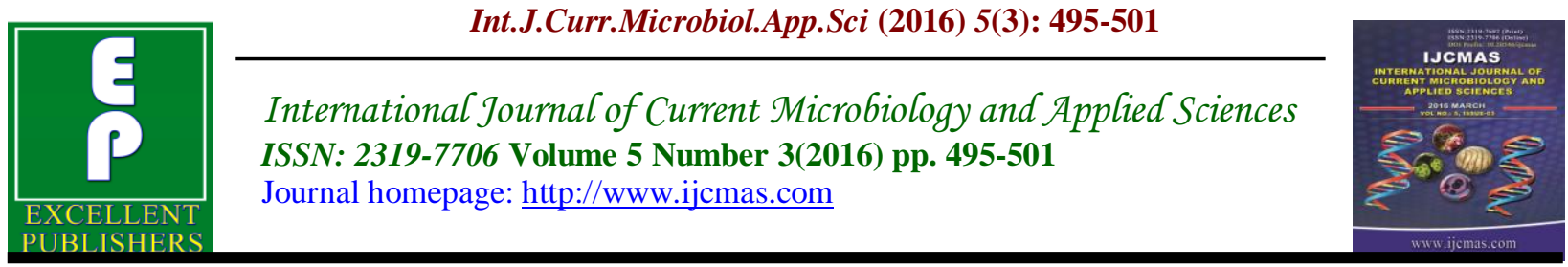

Original Research Article

http://dx.doi.org/10.20546/ijcmas.2016.503.058

\title{
Bacteriological profile of neonatal Septicaemia in MIMS, Mandya, India
}

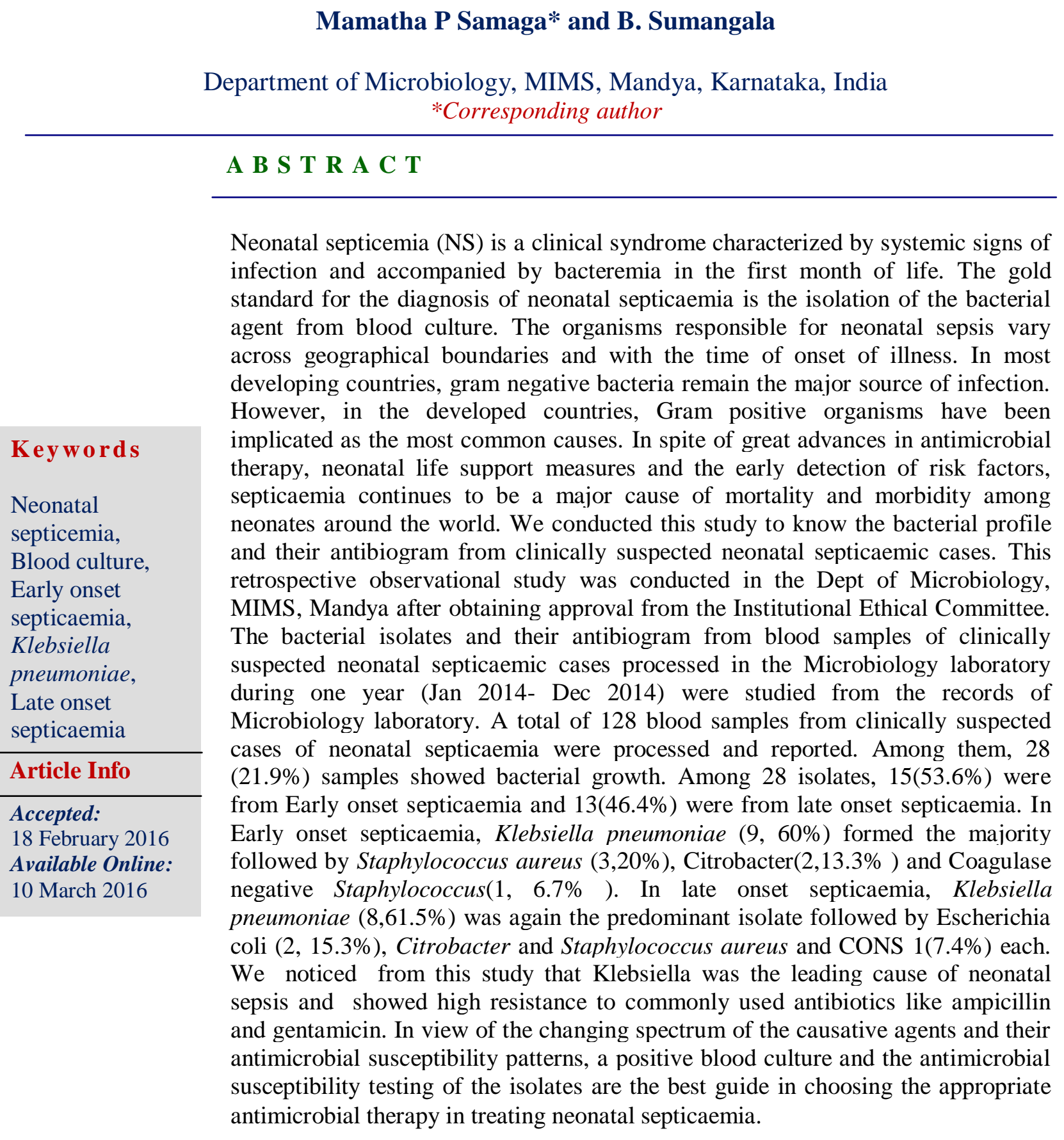




\section{Introduction}

Neonatal septicemia (NS) is a clinical syndrome characterized by systemic signs of infection and accompanied by bacteremia in the first month of life (Freij BJ etal, 2005).The risk factors for neonatal septicemia include premature rupture of membranes, prolonged rupture, prematurity, UTI, poor maternal nutrition, LBW, birth asphyxia and congenital anomalies (Prabhu $\mathrm{K}$ et al., 2010). Depending on the onset of symptoms, it can be classified into early onset sepsis within $72 \mathrm{~h}$ of life and late onset sepsis usually after $72 \mathrm{~h}$ of age (Cloberty JP et al., 1998).

The gold standard for the diagnosis of neonatal septicaemia is the isolation of the bacterial agent from blood culture. For effective management of neonatal septicaemia, study of their antibiotic sensitivity plays a significant role (Forbes BA etal, 2007). The organisms responsible for neonatal sepsis vary across geographical boundaries and with the time of onset of illness (Al-Zwaini EJK, 2002) .In most developing countries, gram negative bacteria remain the major source of infection (Klein JO etal, 2001). However, in the developed countries, Gram positive organisms have been implicated as the most common causes (Plazek M Metal, 1983).

In spite of great advances in antimicrobial therapy, neonatal life support measures and the early detection of risk factors, septicaemia continues to be a major cause of mortality and morbidity among neonates around the world (Guerina NG, 1998).

An area based knowledge of the bacteriological spectrum is necessary because the first antibiotic administered can't wait for the culture results. With the high mortality associated with neonatal septicemia, a right choice of empiric therapy is very important.

Thus we conducted this study to know the bacterial profile and their antibiogram from clinically suspected neonatal septicaemic cases in MIMS, Mandya.

\section{Material and Methods}

Institutional Ethical Committee approval was taken and study was done after ethical clearance.

Study design: This is a retrospective observational study of the reports of blood cultures of all suspected cases of neonatal septicemia in the Dept. of Microbiology of a tertiary care hospital.

Study period: 1 year, Jan- Dec 2014.

Data collection: The bacterial isolates and the antibiogram from blood samples of clinically suspected neonatal septicaemic cases were studied from the records of Microbiology laboratory. $2 \mathrm{ml}$ blood drawn under aseptic precautions and inoculated into $20 \mathrm{ml}$ blood culture bottles were received in the Microbiology laboratory. These blood culture bottles were incubated at $37^{\circ} \mathrm{C}$ under aerobic conditions in the incubator for 7 days. The first subculture was done after 24 hours of incubation, the second on the third day and a final on the seventh day. Subcultures were done onto blood agar and MacConkey agar plates. The inoculated plates were incubated aerobically at $37^{\circ} \mathrm{C}$ for 24 hours, and the plates were observed for growth. The growth was identified by colonial characteristics, gram's stain and standard biochemical tests (Collee JG, 1996). Antimicrobial susceptibility testing of all bacterial isolates was performed by the modified Kirby-Bauer disc diffusion method on Mueller-Hinton agar according to the 
recommendations of the CLSI (CLSI, 2010).

Statistical analysis: Descriptive statistics was used to analyse the data and data was presented as percentage .

\section{Results and Discussion}

A total of 128 blood samples from clinically suspected cases of neonatal septicaemia were processed and reported. Among them, $28(21.9 \%)$ samples showed bacterial growth. Among 28 isolates, 15(53.6\%) were from Early onset septicaemia and 13(46.4\%) were from late onset septicaemia (Fig 1).In Early onset septicaemia (15), Klebsiella pneumoniae $(9,60 \%$ ) formed the majority followed by Staphylococcus aureus (3,20\%), Citrobacter $(2,13.3 \%)$ and Coagulase negative Staphylococcus (1, $6.7 \%$ ). In late onset septicaemia (13), Klebsiella pneumoniae $(8,61.5 \%)$ was again the predominant isolate followed by Escherichia coli (2, 15.3\%), Citrobacter and Staphylococcus aureus and CONS (1,7.4\%) each. The total bacteria isolated and their frequency of distribution is shown in Table 1.Antibiotic sensitivity patterns of Gram negative \& Gram positive bacteria are shown in Table 2 and Table 3 respectively.

The culture positivity rate of bacteria in our study was $21.9 \%$. This is comparable to studies of Kenneth et al.,. who reported 22\%( Kenneth C Iregbu et al., 2006) and Sanjay etal. reported $17.09 \%$ (Sanjay etal., 2012). However a high culture positivity rate of $56 \%$ and $32 \%$ has been reported by Sharma et a1 and Mondal et al., respectively (Sharma etal, 1987; Mondal et al., 1991) .

A low blood culture isolation rate in this study might be due to several reasons like administration of antibiotics before blood collection either to the mother or to the baby or the possibility of infection with anaerobes. Chow et al., reported that $26 \%$ of all neonatal septicemia was caused by anaerobes (Chow et al., 1974).

In our study, early onset septicemia (53.6\%) was more than late onset septicemia (46.4\%), which is consistent with other studies (Aletayab et al., 2011; Waseem R et al., 2005; Al-Shamahy et al., 2012) . This could be due to prematurity, low birth weight and unhygienic conditions during labor.

We found that Gram negative bacteria $(22,78.6 \%)$ were more than Gram positive bacteria $(6,21.4 \%)$. The fetus is frequently exposed to enteric bacteria during the course of maternal peripartal infections. The newborn infant has been shown to have a lack of serum bactericidins against Gramnegative bacilli. These antibodies against somatic or "O" antigens in Gram- negative bacteria are in the gamma-M fraction which is not passed transplacentally from mother to fetus. Hence Gram-negative organisms are commonest cause of neonatal septicemia Overall James, 1970). This predominance of Gram negative organisms as the etiological agent in neonatal septicemia has been corroborated by other workers (Monga K etal 1986; Muley V. A etal, 2002).

We found that in Early onset septicaemia (15), Klebsiella pneumoniae $(9,60 \%)$ formed the major isolate followed by Staphylococcus aureus (3, 20\% ) and Citrobacter $(2,7.1 \%)$ and CONS (1,3.6\%) . In late onset septicaemia (13), Klebsiella pneumoniae $(8,28.6 \%)$ was again the predominant isolate followed by $\mathrm{E}$. coli (2,7.1\%), Citrobacter, Staphylococcus aureus \& CONS 1 (3.6\%)each. Various studies have reported predominant Gramnegative organism as Klebsiella species with an isolation rate of $24.6 \%$ to $42.2 \%$. ( Roy I et al, 2002; Kumhar GD etal, 2002; Kapoor L et al, 2005). 
Table.1 Frequency of Various Bacteria in Eos and Los.Figure in Paranthesis Indicate Percentage

\begin{tabular}{|l|l|l|l|}
\hline Bacteria & EOS & LOS & TOTAL \\
\hline Klebsiella pneumoniae & $9(32.1)$ & $8(28.6)$ & $17(60.7)$ \\
\hline Staphylococcus aureus & $3(10.7)$ & $1(3.6)$ & $4(14.3)$ \\
\hline Citrobacter & $2(7.1)$ & $1(3.6)$ & $3(10.7)$ \\
\hline Escherichia coli & nil & $2(7.1)$ & $2(7.1)$ \\
\hline CONS & & & \\
\hline TOTAL & $1(3.6)$ & $1(3.6)$ & $2(7.1)$ \\
\hline
\end{tabular}

CONS-Coagulase Negative Staphylococcus,EOS-Early Onset Septicaemia, LOS- Late Onset Septicaemia

Table.2 Antibiotic Sensitivity Pattern of Gram Negative Bacteria. Figures in Paranthesis Indicate Percentage

\begin{tabular}{|l|l|l|l|}
\hline & $\begin{array}{l}\text { Klebsiella pneumoniae } \\
\mathrm{N}=17\end{array}$ & $\begin{array}{l}\text { Escherichia coli } \\
\mathrm{N}=2\end{array}$ & $\begin{array}{l}\text { Citrobacter } \\
\mathrm{N}=3\end{array}$ \\
\hline Ampicillin & 0 & 0 & 0 \\
\hline Cotrimoxazole & $2(11.8)$ & 0 & 0 \\
\hline Ciprofloxacin & $6(35.3)$ & 0 & $1(33.3)$ \\
\hline Ceftriaxone & $10(58.8)$ & $1(50)$ & $2(66.6)$ \\
\hline Cefotaxime & $9(53)$ & $1(50)$ & $2(66.6)$ \\
\hline Cefepime & $15(88.2)$ & $1(50)$ & $3(100)$ \\
\hline Imipenem & $16(94.1)$ & $2(100)$ & $3(100)$ \\
\hline Amikacin & $14(82.3)$ & $2(100)$ & $3(100)$ \\
\hline Gentamicin & $9(53)$ & 0 & 0 \\
\hline Tetracycline & $2(11.8)$ & 0 & 0 \\
\hline $\begin{array}{l}\text { Piperacillin- } \\
\text { tazobactam }\end{array}$ & $16(94.1)$ & $2(100)$ & $3(100)$ \\
\hline
\end{tabular}

Table.3 Antibiotic Sensitivity Pattern of Gram Positive Bacteria. Figures in Paranthesis Indicate Percentage

\begin{tabular}{|l|l|l|}
\hline & $\begin{array}{l}\text { Staphylococcus aureus } \\
\mathrm{N}=4\end{array}$ & $\begin{array}{l}\mathrm{CONS} \\
\mathrm{N}=2\end{array}$ \\
\hline Penicillin & $1(25)$ & 0 \\
\hline Erythromycin & $1(25)$ & 0 \\
\hline Tetracycline & $2(50)$ & $1(50)$ \\
\hline Oxacillin & $1(25)$ & $1(50)$ \\
\hline Ciprofloxacin & $2(50)$ & $2(100)$ \\
\hline Cotrimoxazole & $2(50)$ & $2(100)$ \\
\hline Azithromycin & $3(75)$ & $2(100)$ \\
\hline Linezolid & $4(100)$ & $2(100)$ \\
\hline
\end{tabular}


Fig.1 Prevalence of Bacteria in Early and Late Onset Septicaemia (Eos \& Los) Respectively

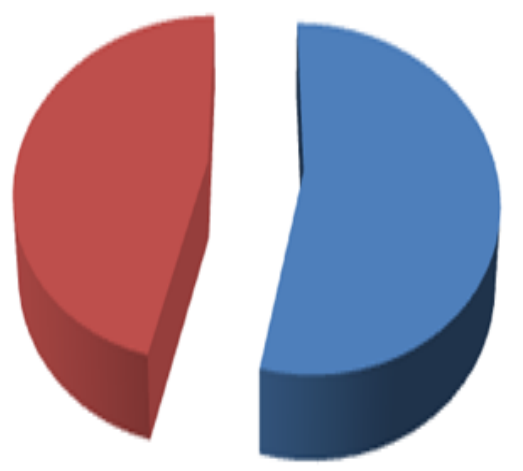

Klebsiella pneumoniae is commonly found in the environment of the neonatal intensive care units and nursery. It can also be present as colonizers on the hands of the health care workers. There are also frequent reports of neonatal septicemia outbreaks due to Klebsiella pneumoniae in nursery and NICUs (Banerjee M et al., 1993)

A comparatively low incidence (21.42\%) of Gram positive organisms has been observed in our study, which correlates well with other studies (Sharma M. etal 2002; Mathur et al., 1994).

The organisms causing neonatal septicaemia differ from area to area and also change with respect to time even in the same area, which may be due to different life conditions (Shrestha P etal, 2007)

The antibiotic sensitivity showed an alarming trend with most of the bacteria showing high resistance to the commonly used antibiotics like Ampicillin and Gentamicin usually employed as the first line of therapy. Similar findings have been reported by Guha et al., and Monga et al., (Guha et al., 1978 and Monga et al., 1986). However, most of the isolates were susceptible to Amikacin and third generation cephalosporins, comparable to the findings from New Delhi and Hubli (Anand NK et al., 1966; Tallur S. S, 2000).

Gram positive bacteria showed $100 \%$ sensitivity to linezolid and Gram negative bacteria showed more than $90 \%$ sensitivity to imipenem. P. Jyothi et al., reported maximum sensitivity of bacteria to imipenem and linezolid. (P Jyothi et al., 2013).

Resistance to commonly used antibiotics is increasing. Establishment of appropriate rational antibiotic policy is essential to control this growing problem. There is an urgent need to do longitudinal surveillance of the microbial flora in every hospital (Deorari, A.K., 2006).

We noticed from this study that Klebsiella was the leading cause of neonatal sepsis, both in early and late onset septicaemia. Klebsiella showed high resistance to commonly used antibiotics like ampicillin and gentamicin. However, most of them were sensitive to amikacin and third generation cephalosporins. Neonatal septicemia is a life-threatening emergency and rapid treatment with appropriate antibiotics plays a important role for a good outcome. In view of the changing spectrum of the causative agents and their 
antimicrobial susceptibility patterns, a positive blood culture and the antimicrobial susceptibility testing of the isolates are the best guide in choosing the appropriate antimicrobial therapy in treating neonatal septicaemia. A careful and regular monitoring of the use of antibiotics at regional and national level is required.

\section{References}

Anand NK., Gupta AK., Mohan M., Lamba IMS., Gupta R., Srivastava L. 1996. Coagulase negative staphylococcal septicemia in newborns. Paediatric Clinics of America. 13:1131-1148.

Al-Zwaini EJK: Neonatal Septicaemia in the Neonatal Care Unit, Al-Anbar governorate, Iraq. East Medit Health J. 2002, 8: 4-5

Aletayeb SMH, Khosravi AD, Dehdashtian M, Kompani F, Mortazavi SM, Aramesh MR. Identification of bacterial agents and antimicrobial susceptibility of neonatal sepsis. African Journal of Microbiology Research 2011; 5(5):528531

Al-Shamahy HA, Sabrah AA, Al-Robasi AB, Naser SM. Types of bacteria associated with neonatal sepsis in AlThawra University Hospital, Sana, Yemen and their antimicrobial profile. SQU Med J 2012; 12(1):48-54

Banerjee M, Sahu K, Bhattacharya S, Adhya S, Bhowmick P, Chakraborty P. Outbreak of neonatal septicemia with multi-drug resistant Klebsiella pneumoniae. Indian J Pediatr. 1993; 60:25-7.

Chow AW, Leake RD, Yarnanchi T. The significance of anaerobes in neonatal bacteremia. Analysis of 23 cases and review of literature. Pediatrics 1974; 54:736-745

Cloberty JP, Stark R. Manual of neonatal case. 1998. p. 271-99

Collee JG, Fraser AG, Marmion BP, Simmons A. Mackie and McCartney Practical
Medical Microbiology. 14th ed. Edinburg: Churchill Livingstone; 1996.

Clinical and Laboratory Standards Institute. Performance standards for antimicrobial disk susceptibility tests; Twentieth informational supplement. CLSI document. M 100-S 20, Vol. 30,1.Jan 2010.p.48-51.

Deorari, A.K. 2006. Changing pattern of bacteriologic profile in neonatal sepsis among intramural babies. J. Neonatol., 20(1): $8-15$.

Freij BJ, George H, McCraken JR. Acute infections. Chapter 48 in NeonatologyPathophysiology and management of the new born. $4^{\text {th }}$ ed. Philadelphia: JP Lippincott Company; p. 1082-116. 2005

Forbes BA, Sahm DF, Weissfeld AS. In: Bailey and Scott's Diagnostic Microbiology.12 ed. Missouri: Mosby Elsevier; 2007:p.779.

Guerina NG. In: Manual of Neonatal Care, 4th ed. (Eds.) Cloherty JP, Stark AR (Lippincott-Raven, Philadelphia) 1998;271-299.

Guha D. K., Jaspal D., Krishna Das M. S. Outcome of neonatal septicemia : a clinical and bacteriological profile. Indian Paediatrics. 15: 423- 428, 1978.

Kenneth C Iregbu, Olumilayo Y Elegba and Iretiola B Babaniyi.Bacteriological profile of neonatal septicaemia in a tertiary hospital in Nigeria. Afr Health Sci 2006;6(3): 151-154.

Klein JO, Marcy MS: Bacterial Sepsis and Meningitis. Infectious Diseases of the Fetus and the Newborn Infant. Edited by: Remington JS, Klein JO. 2001, 943998. Philadelphia: WB Saunders Co, 5 ,

Kumhar GD, Ramachandran VG, Gupta P, Mathur M. Bacteriological analysis of blood culture isolates from neonates in a tertiary care hospital in India. J Health Popul Nutr 2002;20:343-7

Kapoor L, Randhawa VS, Deb M. Microbiological profile of neonatal septicemia in a pediatric care hospital in Delhi. J Commun Dis 2005;37:227-32.

Mondal GP, Raghavan M, Bhat BV. Neonatal 
septicemia among inborn and outborn babies in a referral hospital. Indian $\mathbf{J}$ Pediatr 1991; 58:529-533.

Mathur M., Shah H., Dixit K., Khambadkone S., Chakrapani A., Irani S. 1994. Bacteriological profile of neonatal septicemia cases (for the year 1990-91). Journal of Postgraduate Medicine. 40: $18-20$

Monga K., Fernandez A., Deodhar L.1986. Changing bacteriological patterns in neonatal septicaemia. Indian Journal of Paediatrics. 53: 505-508.

Muley V. A., Shahane V. D., Dohe V. B. et al.,.2002.Neonatal sepsis: Klebsiella pneumoniae as the predominant pathogen. Medical Journal of Western India. 29:108-112.

Overall James, C. Jr. 1970. Neonatal bacterial meningitis: Analysis of predisposing factors and outcome compared with matched control subjects. J. Pediatr., 76(4): 499511.

Prabhu K, Bhat S, Rao S: Bacteriological Profile of Blood Culture Isolates in a pediatric care unit. Journal of Lab Physicians / july - dec 2010 / vol 2: issue 2;85-7

Plazek MM, Whitelaw A: Early and Late Neonatal Septicaemia. Arch Dis Child. 1983, 58: 728-731.

P Jyothi, Metri C. Basavaraj and Peerapur V. Basavaraj, Bacteriological profile of neonatal septicemia and antibiotic susceptibility pattern of the isolates, Journal of Natural Science Biology and
Medicine. 2013; Vol-4 (306-309)

Roy I, Jain A, Kumar A, Aggarwal SK. Bacteriology of neonatal septicaemia in tertiary care hospital of Northern India. Indian J Med Microbiol 2002;20:156-9.

Sanjay D Rathod, Palak V Bhatia, Parimal H Patel, Jayshri D Pethani, Lata R Patel, Bimal Chauhan. 2012. Bacteriological analysis and resistance pattern among various culture isolates from neonatal septicemia at tertiary care hospital of ahmedabad. National Journal of Medical Research. Volume 2(4): 466-469.

Sharma PP, Halder D, Dutta AK. Bacteriological profile of neonatal septicemia. Indian Pediatr 1987; 24:1011-1017.

Sharma M., Goel N., Chaudhary U., Aggarwal R., Arora D. R.. - Bacteraemia in children. Indian Journal of Medical Microbiology. 2002:69(12);1029-1032.

Shrestha P, Das BK, Bhatta NK, Jha DK, Das B, Setia A, Tiwari A. Clinical and bacteriological profile of blood culture positive sepsis in newborns. J. Nepal. Pediatr. Soc.2007; 27(2): 64-67.

Tallur S. S., Kasturi A. V., Nadgir S. D., Krishna B. V. S. - Clinicobacteriological study of neonatal septicemia in Hubli. Indian Journal of Paediatrics. 2000;67(3): 169-174.

Waseem R, Khan M, Izhar TS, Qureshi AW. Neonatal sepsis. Professional Med J $2005 ;$ 12(4):451-456.

\section{How to cite this article:}

Mamatha P Samaga and B. Sumangala. 2016. Bacteriological profile of neonatal Septicaemia in MIMS, Mandya, India. Int.J.Curr.Microbiol.App.Sci. 5(3): 495-501. doi: http://dx.doi.org/10.20546/ijcmas.2016.503.058 